[This paper has been accepted for publication in a revised form in the forthcoming publication: Oran Doyle, Aileen McHarg and Jo Murkens (eds.), The Brexit Challenge for Ireland and the United Kingdom: Constitutions under Pressure (Cambridge University Press, 2021).]

\title{
The Constitutional Politics of a United Ireland
}

\author{
Oran Doyle, David Kenny, Christopher McCrudden*
}

\section{Introduction}

The United Kingdom's withdrawal from the European Union renders a united Ireland more likely than before. Estimates of its likelihood radically diverge, ${ }^{1}$ but unification is now a subject of political discussion. Although Northern Ireland could be incorporated into the existing unitary Irish state without constitutional amendment, unification is likely to be accompanied by significant constitutional change or a new constitution. In this chapter, we explore the modalities and implications of amending Ireland's constitution to make a newly unified state more sensitive to the concerns and aspirations of those from the Ulster Scots and Ulster British traditions. Human rights will, no doubt, form part of this, with specific legal and constitutional protections for minorities. Our focus in this chapter lies elsewhere, however, on what we term the 'constitutional politics' of a united Ireland.

James Bryce, the Nineteenth Century constitutionalist and member of Cladstone's Home Rule Cabinet, notes that political constitutions are exposed to centripetal forces which 'draw[] men or groups of men together into one organized community', and centrifugal forces which 'make[] men, or groups, break away and disperse'. ${ }^{2}$ Bryce argues four factors determine whether a polity will keep together or fall apart: obedience, individualism,

\footnotetext{
* Oran Doyle is professor in law at Trinity College Dublin. David Kenny is assistant professor in law at Trinity College Dublin. Christopher McCrudden Professor of Equality and Human Rights Law, Queen's University Belfast and William W Cook Global Professor of Law at University of Michigan Law School.

${ }^{1}$ In a September 2019 poll, 46 percent of respondents said they would support a united Ireland. '51\% of people in Northern Ireland support Irish unification, new poll finds', thejournal.ie (11 September 2019). In contrast, in the ARK Northern Ireland Life and Times Survey conducted between September 2019 and February 2020, only 25 percent of respondents said they would support a united Ireland. https://www.ark.ac.uk/nilt/2019/Political_Attitudes/REFUNIFY.html.

2 The essay 'The Action of Centripetal and Centrifugal Forces on Political Constitutions' was composed in 1885, but not published until 1901 in James Bryce, Studies in History and Jurisprudence, vol 1 (Oxford: Clarendon Press, 1901), available at: http://oll.libertyfund.org/titles/2003. For an application of Bryce to the analysis of devolution in the UK, see Christopher McCrudden, State architecture: subsidiarity, devolution, federalism and independence, in The Cambridge Companion to Public Law (eds. Mark Elliott and David Feldman) (Cambridge: Cambridge University Press, 2015) 193-214.
} 
interest, and sympathy. Whether these four forces are centripetal or centrifugal in any given state 'depends upon whether they are at the moment giving their support to, or are enlisted in the service of, the State as a whole, or are strengthening the group or groups inside the State which are seeking to assert either their rights within the State or their independence of it.'

In this chapter, we first explore how devolved, consociational government for Northern Ireland could continue within a united Ireland, politically empowering those from the Ulster Scots and Ulster British traditions given that they are likely to be close to 50 percent of the population in Northern Ireland, but only 15 percent of the newly-unified state's population. This might increase the sympathy of those from that tradition for the new state-a centripetal force. But we also show how the operation of devolution could presage a divergence of interests that leads to significant tensions between the national institutions and the devolved institutions, and within the national institutions themselves-a centrifugal force. We then identify the many provisions of the current Irish constitution that posit a notion of Irish identity exclusionary of those from the Ulster Scots and Ulster British traditions. Amendment of these constitutional provisions is surely a sine qua non for increased sympathy for the unified State. Many of these provisions, however, manifest and reflect indicia of Irish identity dearly held by many if not most citizens of the current Irish state. Their removal-at least without detailed consideration of how the constitution might be amended to respect multiple identities-risks reducing the sympathy of existing citizens for the unified State.

In exploring these issues, we do not advocate a united Ireland or any particular constitutional provisions, but seek to draw attention to the complexities involved in balancing centripetal and centrifugal forces. If a united Ireland is to occur, far better that these issues be anticipated both in their complexity and their sensitivity. But the task would extend long past the moment of unification. We therefore conclude by exploring how the various constitutional changes considered would be interpreted and amendable after unification. In all of this, we take no position on whether Irish unification is desirable, nor whether any of these changes should be considered-save those we identify as required by the Belfast - Good Friday Agreement ('the Agreement').

The problem of terminology haunts political discourse on the island of Ireland. We have generally adopted conventional usage of contested terms, whilst distancing ourselves 
from accepting the political implications that some would place on that use. Thus, for example, we refer to the 'unification' of Ireland, rather than 're-unification', whether or not the latter term may be historically justified. There is one area, however, where no clear conventional usage has yet emerged: what are we to call those who were 'unionists' and self-identified as 'British' in Northern Ireland pre-unification, but would-in the possible future that this chapter explores-find themselves in a united Ireland? We are particularly sensitive that we should not assume how that community may come to self-identify, nor should we assume that such a community will not change its identity over time. 'Unionists' suggests that they remain committed to a 'union' that would no longer exist. 'British' assumes a loyalty they may no longer have. 'Protestants' over-emphasizes the religious dimension and insufficiently distinguishes them from co-religionists in the South. Moreover, this community's identity is likely to affect, and be affected by, the issues that we discuss in this chapter. For want of anything better, and in the knowledge that unionist representatives themselves accepted the designation in New Decade, New Approach re-establishing devolved government in Northern Ireland, ${ }^{3}$ we shall refer to 'those from the Ulster Scots and Ulster British traditions', with apologies in advance to anyone offended by this usage. One final comment on terminology is necessary. We later explore the possibility that the Irish-language titles of state institutions might be altered in a united Ireland. We largely adopt the current terminology for our analysis, however, even when discussing post-unification institutions: Oireachtas (parliament), Dáil (lower House), TD (member of the Lower House), Seanad (Upper House), and Taoiseach (prime minister).

Finally, we should outline our understanding of how unification might take place. ${ }^{4}$ Under the Belfast - Good Friday Agreement and the Constitution of Ireland, ${ }^{5}$ unification requires concurrent referendums North and South, at least if unification is accompanied by any of the constitutional changes discussed here. Concurrence does not require simultaneity but does require that the two electorates approve substantively the same proposal. This leaves open a wide range of options, the key variable being the extent to which the unification terms are resolved before or after the referendums. In this chapter, we prescind

\footnotetext{
3 New Decade, New Approach (January 2020), available at: https://assets.publishing.service.gov.uk/government/uploads/system/uploads/attachment_data/file/8569 98/2020-01-08 a new decade a new approach.pdf.

${ }^{4}$ CRG Murray and Aoife O'Donoghue, 'Life after Brexit: Operationalising the Belfast/Good Friday Agreement's Principle of Consent' (2019) 42(1) DULJ XX.

${ }^{5}$ Article 3.
} 
from those questions but our discussion is framed by this understanding. ${ }^{6}$ We take the current Irish constitution as the baseline of analysis, but do not differentiate between constitutional amendment and constitutional replacement as mechanisms of constitutional change.

\section{Devolution and Consociationalism in Northern Ireland}

\subsection{The Belfast-Good Friday Agreement}

The Agreement involves two connected and cross-referring agreements: an international agreement between the British and Irish Governments; and a multi-party agreement between the parties in Northern Ireland and the two Governments. ${ }^{7}$ The Agreement was brought into UK law primarily by the Northern Ireland Act 1998 (UK) ('NIA 1998'). Although the institutions established were frequently suspended when the political parties failed to agree, and the details of how the institutions were to operate have been amended in subsequent agreements, the basic structure of the Agreement has remained. The Agreement consists of three strands: relationships within Northern Ireland; relationships between Northern Ireland and the South; and relationships between Britain and Ireland. Institutions were developed under each of these strands to reflect these interlinking relationships, considered further below. The Agreement crucially includes other provisions dealing with the constitutional status of Northern Ireland, the decommissioning of paramilitary weapons, the release of paramilitary prisoners, and human rights and equality.

\section{$\underline{2.2 \text { Devolution }}$}

The Agreement was concluded, and the NIA 1998 devolving powers from Westminster to Belfast passed, at the same time as the devolution of powers to Wales and Scotland. ${ }^{8}$ The

\footnotetext{
${ }^{6}$ See generally Alan Renwick, Alan Whysall et al, Interim Report of Working Group on Unification Referendums on the Island of Ireland Constitution Unit, UCL (October 2020) (forthcoming).

${ }^{7}$ This section draws on more detailed analysis in Christopher McCrudden, Northern Ireland and the British Constitution Since the Belfast Agreement, in The Changing Constitution (eds Jeffrey Jowell and Dawn Oliver) (Oxford University Press, 2007), 227-270.

${ }^{8}$ Government of Wales Act 1998; Scotland Act 1998.
} 
Northern Ireland arrangements are similar to devolution in Scotland and Wales-as they have developed-with devolved assemblies and executives, exercising powers over a relatively similar set of issues, with a relatively similar set of other issues being reserved to Westminster. The NIA 1998 identifies three categories of functions, 'excepted,' 'reserved', and 'transferred'-in only the latter two has the Assembly any powers to legislate. ${ }^{9}$ Only in the case of transferred functions does the Assembly have full authority to pass primary legislation for Northern Ireland, subject to the European Convention on Human Rights and the provisions of the Ireland-Northern Ireland Protocol to the Withdrawal Agreement between the EU and the UK. The operation of these devolved powers is governed by UK law, as ultimately interpreted by the United Kingdom Supreme Court.

The devolution of powers to Scotland, Wales and Northern Ireland are-as a matter of UK law-equally subject to being overridden by the Westminster Parliament, simply by repealing the devolution statutes. Parliamentary sovereignty thus continues to reign supreme. Of greater practical importance is the way in which Westminster can adjust the practice of devolution, whether by altering the scope of competences devolved or by choosing to legislate in respect of a particular issue notwithstanding that competence has been devolved. A set of constitutional conventions and understandings has grown up which regulate the relationship between Westminster and the devolved assemblies. In particular, the so-called Sewel Convention provides that Westminster will not normally legislate in devolved areas without the consent of the devolved assembly. But these operate in the political rather than the legal domain, and thus remain legally unenforceable, even though incorporated into Scottish and Welsh devolution statutes. ${ }^{10}$ Brexit has strained the Sewel Convention to breaking point, with the UK Parliament overriding decisions of the Scottish Parliament, and the Welsh and Northern Ireland Assemblies, which refused consent to legislation at Westminster affecting the operation of devolved powers. ${ }^{11}$

Another area of similarity between the devolution arrangements is the response to the so-called 'West Lothian' question. In the absence of devolution for England, why should MPs from Scotland, Wales, and Northern Ireland be permitted to vote on specifically

\footnotetext{
${ }^{9}$ NIA 1998, section 4.

${ }^{10}$ Miller et al v. Secretary of State for Exiting the European Union [2017] UKSC 5.

${ }^{11}$ For details, see https://www.instituteforgovernment.org.uk/explainers/sewel-convention.
} 
English issues, while English MPs may not vote on those issues devolved to Scotland, Wales, and Northern Ireland? The current solution to this problem is known as 'English Votes for English Laws' (EVEL), whereby MPs from the devolved nations and regions have agreed not to participate in some votes on English issues. A new stage is added to the usual law-making process at Westminster allowing MPs for English constituencies to vote on issues that only affect England. ${ }^{12}$ These English MPs are able to veto the legislation before it comes before all MPs in the final stage. ${ }^{13}$ EVEL is potentially a source of constitutional instability at Westminster, as the UK government must maintain a dual legislative majority if it is to govern effectively: one for the UK and one for England. The risk of constitutional instability is reduced, however, by English MPs making up 82 percent of the membership of the House of Commons, and by the UK electoral system providing a significant seat-bonus to the winning party. ${ }^{14}$

Notwithstanding the considerable similarities between the devolved administrations, the Agreement broke new institutional and constitutional ground in British constitutional terms, setting Northern Ireland apart from Wales and Scotland. First, Northern Ireland's system of government is based on a model of cross-community power-sharing termed 'consociationalism'. Second, it is connected to a broader set of institutions and embedded in an international agreement between Ireland and the United Kingdom. Third, the Agreement provides for Northern Ireland to leave the UK if the majority of its people vote at a referendum for unification with the South. The devolutionary arrangements, therefore, anticipate a possible change of constitutional status; as discussed later, devolved institutions might even persist post-unification.

Brexit has foregrounded a further tension between British constitutional practice and the constitutional arrangements for Northern Ireland envisaged by the Agreement. In Britain, or at least in England, the constitution is the outward manifestation of a substantial degree of consent, or at least acquiescence. Traditionally, constitutional procedures in Britain derive from that consent or acquiescence to the legitimacy of the state. ${ }^{15}$ In Northern Ireland, given the absence of consent from a significant proportion of the

\footnotetext{
${ }^{12}$ Introduced by changes to the House of Commons' Standing Orders on 22 October 2015.

13 For a detailed explanation of the procedure, see https://www.parliament.uk/about/how/laws/bills/public/english-votes-for-english-laws/.

${ }^{14}$ Daniel Gover and Michael Kenny, Answering the West Lothian Question? A Critical Assessment of 'English Votes for English Laws' in the UK Parliament, Parliamentary Affairs, Volume 71(4) 2018, 760-782.

${ }^{15}$ See further, McCrudden, above note 7.
} 
population in the recent past, there have been attempts to construct consent in part on the basis of constitutional guarantees. Brexit threatened (and continues to threaten) that agreed status quo. In particular, the power of Westminster to alter the precise contours of the devolution settlement in Northern Ireland might be exercised in a way that undermines the consent to the state that devolution was intended to construct. ${ }^{16}$ Similar issues might arise in reverse in a united Ireland, as we shall see below.

The 'domestic' Northern Ireland institutional structures exist in a broader framework. North-South governmental activity was formalized in three ways: a North-South Ministerial Council, cross-border 'implementation bodies' for specified issues, and a looser arrangement for agreed cooperation between bodies with jurisdiction over designated functions in the two jurisdictions. There would be little reason for these NorthSouth institutions to continue in the event of unification, so we do not consider them further here.

East-West co-operation, however, potentially retains significance post-unification. Two institutions were established: a British-Irish Council (BIC) and a British-Irish Intergovernmental Conference (BIIC). The BIC was established 'to promote the harmonious and mutually beneficial development of the totality of relationships among the peoples of these islands'. Membership of the BIC comprised representatives of the United Kingdom and Irish governments, representatives of devolved institutions in Northern Ireland, Scotland, and Wales, and representatives of the Isle of Man and the Channel Islands. Of considerably greater practical importance, however, a standing British-Irish Intergovernmental Conference was also established, subsuming institutions established under the earlier 1985 Anglo-Irish Agreement. The BIIC is a forum in which the British and Irish governments formally discuss Northern Ireland. We consider the relevance of the BIIC in a united Ireland in section 6.

\section{$\underline{2.3 \text { Consociationalism }}$}

\footnotetext{
${ }^{16}$ Christopher McCrudden and Daniel Halberstam, Miller and Northern Ireland: A Critical Constitutional Response, The UK Supreme Court Yearbook. 2018.
} 
At the risk of considerable oversimplification, ${ }^{17}$ there are two broad options for democratic states that incorporate a multi-ethnic or multi-national population: the state may choose either to eliminate or to manage the differences in ethnic or national identity. Elimination may involve policies of assimilation, or liberal integrationist approaches: majority rule accompanied by minority rights protections. Management can involve geographically-based confederal or federal arrangements. Two other approaches, however, have attracted significant scholarly and political attention: first, associated with Horowitz, encouraging the different ethnic or national groups to cross their tribal boundaries; ${ }^{18}$ second, associated with Lijphart, encouraging power-sharing through the adoption of what has been termed 'consociationalism'. 19

Consociations are commonly thought to contain four key elements: ${ }^{20}$ parity of the contending groups through cross-community power-sharing (shared-government); community autonomy over some decision-making (self-government); proportional representation in shared institutions; and veto rights on vital issues. Northern Ireland has embedded consociationalism across these four dimensions: parity through crosscommunity power-sharing is evident in executive formation, requiring cross-community government; community autonomy over some decision-making is provided especially on issues of primary and secondary education; proportional representation in shared institutions is seen in the composition of the police and the civil service; veto rights on vital issues are possible through the 'petition of concern' mechanism.

Elections to the Assembly are by single transferable vote system of proportional representation (PR-STV). In these Assembly elections, the Democratic Unionist Party (DUP) and Sinn Féin have emerged as the largest unionist and nationalist parties respectively. Together with the Ulster Unionist Party (UUP), the Social Democratic and Labour Party (SDLP), and Alliance, these comprise the five largest parties. In these results, we can identify another important feature of Northern Ireland that stands in marked contrast to politics in the rest of the United Kingdom and in Ireland: the virtual absence of UK-wide and (with the exceptions of Sinn Féin and the Green Party) Ireland-wide political parties in Northern Ireland.

\footnotetext{
${ }^{17}$ This section draws on Christopher McCrudden and Brendan O'Leary, Courts and Consociations: Human Rights versus Power-sharing (Oxford: Oxford University Press, 2013).

${ }^{18}$ D Horowitz, Ethnic Groups in Conflict (Berkeley: University of California Press, 1985).

${ }^{19}$ A Lijphart, Democracy in Plural Societies: A Comparative Exploration (New Haven: Yale University Press, 1977).

${ }^{20} \mathrm{McCrudden}$ and O'Leary, above note 17.
} 
Safeguards require both parts of the community to participate and work together in the operation of the Assembly. Members of the Assembly are, controversially, required to register a designation of identity (nationalist, unionist, or other) for the purposes of measuring cross-community support in Assembly votes. Key decisions are taken on a cross-community basis. This involves either 'parallel consent'-that is, a majority of those members present and voting, including a majority of the unionist and a majority of the nationalist designations present and voting-or a weighted majority (60 per cent) of members present and voting, including at least 40 per cent of each of the nationalist and unionist designations present and voting. ${ }^{21}$

Key decisions in the Assembly requiring cross-community and concurrent majority support include the election of the presiding officer of the Assembly (equivalent to the Speaker at Westminster); the election of the First Minister and Deputy First Minister; the adoption of standing orders; the exclusion of a person or party from ministerial office; and budget allocations. In other cases, a 'petition of concern' brought by at least 30 Assembly members triggers decisions requiring cross-community support. The Chairs and Deputy Chairs of the Assembly Committees, shadowing the main executive functions, are allocated proportionally, using the d'Hondt system. Membership of the Committees is in broad proportion to party strengths in the Assembly. These requirements are intended to ensure that both communities in Northern Ireland support Assembly decisions and prevent the simple majoritarianism that operated in Northern Ireland prior to 1972.

The Northern Ireland Executive consists of a First Minister and a Deputy First Minister and up to ten ministers with departmental responsibilities (with additional junior ministers that can be appointed.) The First Minister and Deputy First Minister are jointly elected into office by the Assembly voting on a cross-community basis according to the 'parallel consent' method discussed above. The posts of ministers are then allocated, in sequential order, to parties on the basis of the d'Hondt system, by reference to the number of seats each party has in the Assembly. The Executive is convened, and presided over jointly, by the First Minister and Deputy First Minister, whose functions include dealing with and coordinating the work of the Executive and the response of the Northern Ireland administration to external relationships. ${ }^{22}$

\footnotetext{
${ }^{21}$ NIA 1998, section 4.

${ }^{22}$ NIA 1998, Part III.
} 
Consociationalism also has considerable reach into other dimensions of life in Northern Ireland. An important aspect of 'normalization' involved the creation of a police force which all sections of the population could recognize as legitimate, and to which they could give their consent and support. Central to encouraging cross-community support for these arrangements was a system of recruitment (now discontinued) to ensure that the new police service would be more representative of the community as a whole. ${ }^{23}$

\subsection{Devolution and consociationalism post-unification}

How might Northern Ireland's current governmental structures continue, if at all, in a united Ireland? One approach would be for the new Irish state to operate as a single entity, without special arrangements for Northern Ireland. Another would be national consociationalism for a unified, unitary Irish state, with a new Irish Parliament and Government composed on the same basis as the existing Northern Ireland Assembly and Executive. Operationalizing this option would raise significant questions, and (so far as we are aware) is not strongly advocated in any of the present debates on this topic.

A third approach, and the focus of this chapter, would continue consociational arrangements in a Northern Ireland Assembly and Executive in a similar manner as currently operating, but with sovereignty shifting from London to Dublin. Whether as a requirement of the Agreement or not, this is considered by some to be the most appropriate way of recognizing the values embedded in the Agreement. ${ }^{24}$ If even greater autonomy were given to the region in a unified Ireland, this would cease to look like devolution and would become a 'federal', or even 'confederal' model. Such a possibility merits separate consideration in more detail than we can provide here. ${ }^{25}$ In the next section, we explore the implementation of devolution and consociationalism in a united Ireland broadly similar to the current arrangements under the Agreement.

\footnotetext{
${ }^{23}$ A New Beginning: Policing in Northern Ireland: The Report of the Independent Commission on Policing for Northern Ireland (September 1999) (the 'Patten Report').

${ }^{24}$ Richard Humphreys, Beyond the Border (Merrion Press, 2018) 117 argues that this is a requirement. Others see it as a prudential judgment to be made, as aspects of the agreement may be difficult to resile from; Sylvia de Mars, Colin Murray, Aoife O'Donoghue, and Ben Warwick, Bordering Two Unions: Northern Ireland and Brexit (Policy Press, 2018) 88.

${ }^{25}$ See Brendan O'Leary, 'The Choices on the Future Menu' IACL-IADC Blog (25 February 2020) https://blogiacl-aidc.org/irish-unification/2020/2/25/the-choices-on-the-future-menu.
} 


\section{Constitutional changes necessary to accommodate devolution/consociationalism}

\section{$\underline{3.1 \text { Devolved legislative and executive powers }}$}

The current Irish state is unitary, highly centralised, and executive-dominated. ${ }^{26}$ Local government is weak, both as a matter of constitutional principle and in practice. ${ }^{27}$ There is no tradition of or experience with regional government. Existing constitutional provisions might allow the integration of some devolved institutions, but probably not the continuation of the devolved institutions that currently exist in Northern Ireland. Article 15.2 of the Irish Constitution vests the legislative power exclusively in the Oireachtas, while allowing the Oireachtas to create or recognise subordinate legislatures, as well as specifying their powers and functions. A unified Ireland could, therefore, accommodate a devolved legislature in Belfast, but the extent of the powers that could be granted to that legislature is unclear. ${ }^{28}$

The possibility of subordinate legislatures is a limited qualification to the emphatic statement that the Oireachtas holds sole and exclusive legislative authority. Without invoking this provision, the courts have allowed the delegation of law-making power to other entities, such as Government Ministers, subject to limits that might not fully apply in constitutionally-authorised 'subordinate legislatures'. ${ }^{29}$ But 'subordinate' implies limitations on any devolved legislature in Belfast that are probably broadly equivalent to those that currently pertain in the UK, considered in section 2.2 above. The Oireachtas could not alienate power permanently to a devolved legislature; the Oireachtas could revoke devolution or alter its scope in the future; and the Oireachtas could-if it wishedlegislate in respect of a matter on which competence had been devolved to the subordinate legislature.

\footnotetext{
${ }^{26}$ See John Coakley and Michael Gallagher (eds.) Politics in the Republic of Ireland ( $6^{\text {th }}$ ed, Routledge, 2018). See also David Kenny and Conor Casey, 'The Resilience of Executive Dominance in Westminster Systems: Ireland 2016-2019', (2021) Public Law (forthcoming).

${ }^{27}$ Article $28 \mathrm{~A}$ provides constitutional recognition for local government, but the Oireachtas has granted only limited powers.

${ }^{28}$ Gerard Hogan, Gerry Whyte, David Kenny and Rachael Walsh, Kelly: the Irish Constitution (5th ed, Bloomsbury, 2018) [4.2.94].

${ }^{29} \mathrm{Ibid}$ [4.2.09-93]. Moreover, this jurisprudence is not particularly strict in terms of its judicial application, and some have called for the test to be reformulated. See ibid [4.2.50-51].
} 
It is also unclear whether executive powers could be devolved at all. There is no provisionparallel to that in Article 15.2-to create or recognise a subordinate executive, still less provide for its powers or functions. Moreover, the courts have held, in the context of foreign affairs, that the Government cannot delegate its own executive power. ${ }^{30}$ The courts have recognised, in the immigration context, the power of the Oireachtas to legislate in a way that removes an aspect of the executive power and assigns it to an administrative agency. ${ }^{31}$ But this would be quite different from creating a separate executive to execute the laws of a different legislature. It could be argued that the authorisation of devolved legislatures implies the permissibility of a devolved executive, but this is highly contestable. Article 3 allows for the establishment of North-South bodies with executive powers and functions, but this appears limited to the preunification institutions envisaged by Strand 2 of the Agreement.

The financial competences of devolved institutions in Belfast would remain limited; the Irish Constitution provides for a budgetary system for taxation and expenditure. ${ }^{32}$ These lie entirely in the bailiwick of the Government and the Dáil and could not be devolved to any subordinate legislatures and executive that might be created. ${ }^{33}$ The Northern Ireland institutions could probably hold the same limited financial competence as is currently the case, but the devolution of any wider financial competence would likely be unconstitutional. More generally, the State would remain bound by the Treaty on Stability, Coordination and Governance in the Economic and Monetary Union (the Fiscal Compact Treaty), effected in Irish law by the Fiscal Responsibility Act 2012. The obligations of debt and deficit control under this Treaty would likely reduce the national Government's willingness to concede greater financial autonomy to Northern Ireland than the UK Government currently has. ${ }^{34}$

In short, while there are possible constitutional bases for the continuation of Northern Ireland's devolved institutions in the event of unification, such an approach is fraught with

\footnotetext{
${ }^{30}$ Crotty v An Taoiseach [1987] IR 713.

${ }^{31}$ Laurentiu v Minister for Justice [19994] 4 IR 26.

${ }^{32}$ In Articles 11, 17, 21 and 22.

${ }^{33}$ See Kelly (n 28) [3.4.27-50], [4.5.08]-[4.5.17].

${ }^{34}$ There are constitutional issues around the economics of unification that need to be considered, from institutional divergence between the economies of the South and North would need to be bridged (intensified by Ireland's Eurozone membership) to broader questions of the economic constitution of a united Ireland. These must await another occasion.
} 
constitutional risk; even on the most permissive of interpretations, the devolution of some further competences is likely to be stymied.

\subsection{Consociationalism}

The consociational arrangements required by the Agreement for Northern Ireland's devolved institutions could not-without constitutional change-be replicated at the national level in a united Ireland. The Constitution provides that all questions in each House of the Oireachtas must be determined by a majority vote. ${ }^{35}$ This requirement for majority voting might, by implication, extend to subordinate legislatures also, given that they exercise-albeit in a delegated manner-the same legislative power as the Oireachtas.

The problems with the constitutionality of a devolved executive, discussed above, are exacerbated in the context of a consociational/power-sharing executive. There being no equivalent to this in the Irish constitutional order, it is unclear whether it is permissible to divide executive power or compose an executive in this way. It could be argued that any delegated executive should function in broadly the same manner-mutatis mutandis by reason of being a delegate-as the national executive. This would require, e.g., the executive to be appointed on the nomination of a first minister who secures simple majority support of the assembly, and who nominates-at his or her discretion-a cabinet from amongst the members of the legislature which is subject to the approval of the legislature. ${ }^{36}$ As against this, if a devolved executive in Northern Ireland is conceived not as a delegate of delegated executive power, but rather as an assignee of powers removed from the national government by the Oireachtas, these objections might hold less force.

More broadly, consociationalism as practised in Northern Ireland requires crosscommunity representation in various aspects of governance, notably in Northern Ireland policing and to some extent the staffing of the civil service. Even if consociational requirements in these contexts were seen as prima facie unequal, the risk of judicial invalidation is low. The Constitution guarantees equality before the law, but allows for

\footnotetext{
${ }^{35}$ Article 15.11 .

${ }^{36}$ See Article 28.5-6; Article 13.1-13.2.
} 
due regard to differences of capacity, physical and moral, and of social function. ${ }^{37}$ Moreover, the courts have-to say the least-enforced the equality guarantee in a highly deferential manner. ${ }^{38}$

\subsection{Constitutional amendments required to allow for devolution and consociationalism}

There are, therefore, significant constitutional doubts as to whether the current devolution and consociational aspects of Northern Ireland governance could continue in a united Ireland without constitutional amendment. It would be prudent, if it were desired to continue these institutional arrangements, to provide a complete constitutional basis rather than simply attempt to plug the constitutional gaps identified above. The following issues would need to be addressed:

- The establishment of devolved legislatures and executives, with some indication as to their range of competences;

- The establishment of new financial arrangements that provide devolved institutions with financial competence while ensuring that Ireland continues to meet its obligations under the Fiscal Compact Treaty;

- The authorisation of consociational features for the devolved institutions, including parallel consent, weighted majority voting, petitions of concern, and executive formation;

- The authorisation of consociational features in other domains, such as policing.

The basic design choice is whether to empower the Oireachtas to create the relevant institutions or to establish those institutions in the Constitution itself. If the former, the Oireachtas would retain a relationship of superiority over the devolved institutions similar to that currently enjoyed by Westminster -- arguably greater if Strand One of the Agreement is superseded by unification, since then there would be no obligation in international law to preserve the devolved institutions in Northern Ireland. If the latter, the issues regulated in the Constitution could only be changed by further constitutional amendment, thereby rendering devolution more rigid, and enhancing the power of the Irish Supreme Court as interpreter of these provisions. In either scenario, there would be

\footnotetext{
${ }^{37}$ Article 40.1.

${ }^{38}$ See Kelly (n 28) [7.2.01]-[7.2.157].
} 
continuing issues about the day-to-day management of relations between the national parliament and government and the devolved institutions in Belfast. We explore these issues in the next section.

\section{The Political Challenges of Managing Devolution and Consociationalism}

The first such challenge raised by the continuation of devolution in a united Ireland is the 'West Belfast question': why should TDs from Northern Ireland get to vote on issues that affect only the South, when TDs from the South would not get to vote on issues devolved to an assembly in Belfast? The risk of constitutional instability associated with this question would be far higher in a united Ireland than the equivalent question in the UK considered above, given the higher proportion of Northern TDs in the national parliament (30 percent) and the PR-STV electoral system. It is readily conceivable that an Irish Government in a unified state could be elected with the support of Northern TDs but lack a majority among TDs from the South. This could be problematic if the Oireachtas were to enact laws for the South that were opposed by a majority of TDs from the South. Political controversy would surely arise if Northern TDs supported less generous public spending arrangements for the South than those which their parties supported for the North, whether through the devolved institutions or financial negotiations with the national government.

The UK's EVEL 'solution', discussed in section 2.2, would be more difficult to implement in a united Ireland, for the same reasons as make the West Belfast question itself a greater source of instability. The PR-STV electoral system, with each passing election, produces an increasingly fragmented party system in the South, making government formation more difficult. With 30 percent of TDs drawn from Northern Ireland, it would be even more challenging to form a Government with a legislative majority both for the state as a whole and for the South. While it is difficult to predict how an electoral system in a united Ireland would play out in practice, the implementation of an EVEL-variant in a united Ireland would likely be problematic.

The second challenge arises from the daily management of relations between the devolved region and the centre. In the current devolution settlement for Northern Ireland, statute determines what matters are devolved to Stormont and what matters are kept at 
Westminster. The powers of Stormont are, therefore, subject to override by Westminster most relevantly by either the withdrawal of a particular competence or by national legislation within a field of devolved competence. If the Irish constitution were amended to provide a clear legal power for the Dublin Parliament to create devolved institutions in Belfast broadly similar to those that currently operate, devolution would be subject to the same constitutional insecurities as devolution in the UK. Constitutional conventions have not been entirely successful at mediating these conflicts in the UK, but would hold even less purchase in an Irish state, where there is no tradition of constitutional actors explicitly constraining their own actions with reference to conventions. These insecurities might undermine one of the core reasons for continuing devolution in the first place: to assuage the concerns of those from the Ulster Scots and Ulster British traditions.

On the other hand, while specifying the devolution of competences in the constitution itself might provide reassurance to voters in the North, it would reduce the flexibility of the devolution settlement. Any change to the terms of devolution would require a constitutional amendment. This is not a far-fetched scenario: devolution and power sharing are very complex, and their implementation in a united Ireland would bring new and unexpected challenges. Given that amendments were made to the functioning of the Agreement institutions in the St Andrews Agreement within a decade of its signing, it is entirely possible that significant changes might also be required in a united Ireland. Constitutional entrenchment, with its requirement of a referendum for amendment, could impede swift and necessary reform. Moreover, the Stormont institutions have been suspended on a number of occasions when consociational governing arrangements have broken down. In such cases, it was a relatively straightforward matter-under the UK constitutional system-for the UK government to step in to secure continuity. This would not be possible for an Irish government in Dublin if the terms of devolution were entrenched in the Constitution. Of course, provision could be made to allow for Dublin to suspend devolution in certain circumstances, but the very existence of such a unilateral power could recreate the distrust that the continuation of devolution and its protection in the constitution were supposed to address.

Consciationalism within the devolved Northern institutions, in contrast, poses few direct challenges to day-to-day relationships with the institutions of the broader, unified State. Indeed, a consociational executive in Belfast might be better placed to manage good relations with the Dublin government, since the devolved administration in Belfast could 
not be dominated by parties opposed to the government in Dublin. The continuation of consociationalism in the PSNI would, however, imply the continuation of two discrete police services. The relationships between these services would need to be clarified.

\section{Constitutional accommodation of Ulster-Scots and Ulster-British identity}

\subsection{Overview}

A crucial aspect of any constitutional settlement in a united Ireland is how it would accommodate and provide for the identity of those from the Ulster-Scots and Ulster-British traditions. ${ }^{39}$ This is not only highly desirable to enable people from those traditions feel sympathy for the new State; it is also essential to honour the commitments in the Agreement, ${ }^{40}$ where there are several seemingly enduring commitments to respect the identities of groups in Northern Ireland. Whatever choice is made by the people of Northern Ireland, the Agreement states,

'the power of the sovereign government with jurisdiction there shall be exercised with rigorous impartiality on behalf of all the people in the diversity of their identities and traditions and shall be founded on the principles of ... parity of esteem and of just and equal treatment for the identity, ethos, and aspirations of both communities'. ${ }^{41}$

The parties further 'recognise the birthright of all the people of Northern Ireland to identify themselves and be accepted as Irish or British, or both, as they may so choose. ${ }^{142}$ These commitments explicitly apply in a united Ireland. Respecting them requires accommodation of the identity and ethos of those from the Ulster-Scots and Ulster-British traditions, and this should be reflected at the constitutional level, where the most fundamental commitments to values are enumerated.

\footnotetext{
${ }^{39}$ See for a more detailed account, see David Kenny, 'The Irish Constitution, a United Ireland, and the Ship of Theseus: Radical Constitutional Change as Constitutional Replacement' <https://papers.ssrn.com/sol3/papers.cfm?abstract id=3399054>.

${ }^{40}$ Brice Dickson, 'Unionist fears in a United Ireland' IACL-IADC Blog (27 February 2020), <https://blog-iaclaidc.org/irish-unification/2020/2/27/unionist-fears-in-a-united-ireland>.

${ }^{41}$ Belfast- Good Friday Agreement, Constitutional Issues, para 1(v).

${ }^{42}$ Belfast- Good Friday Agreement, Constitutional Issues, para 1(vi).
} 


\subsection{Symbols}

Symbolic accommodation of these traditions in the Irish Constitution would have two elements: what should be removed, and what should be added. Parts of the Preamble to the Irish Constitution are not only religiously sectarian (reflecting Catholic political theology) but also politically sectarian (reflecting Irish nationalist tropes). ${ }^{43}$ Those from non-Catholic or non-nationalist traditions may consider themselves excluded from the Preamble's 'We, the people ....' ${ }^{44}$ A new Preamble, based perhaps on values in the Agreement, and specifically acknowledging the Ulster-Scots and Ulster-British traditions, would be needed.

Article 2 of the Constitution outlines the concept of an 'Irish nation', one which 'cherishes its special affinity with people of Irish ancestry living abroad who share its cultural identity and heritage'. This should be redrafted in order to acknowledge that a new national identity centrally includes the Ulster-Scots and Ulster-British traditions. Article 7 dictates that the national flag be the tricolour of green, white and orange, a flag with long and controversial associations with the conflict in Northern Ireland. ${ }^{45}$ If a unified Ireland is to have a flag with which all citizens can identify, including those from the Ulster-Scots and Ulster-British traditions, Article 7 would require amendment.

Perhaps the most challenging accommodation of the Ulster-Scots and Ulster-British traditions would be acknowledgement or recognition of the British monarch. Various commentators have suggested that a united Ireland could rejoin the Commonwealth of Nations, of which it was a member until $1949,{ }^{46}$ and the Constitution was clearly drafted to permit Commonwealth membership. ${ }^{47}$ For as long as the British monarch remains Head of the Commonwealth, Irish membership would imply some recognition of that

\footnotetext{
${ }^{43}$ It speaks of 'our fathers' enduring 'centuries of trial' in a 'heroic and unremitting struggle' to obtain independence.

${ }^{44}$ Oran Doyle, The Irish Constitution: A Contextual Analysis (Hart, 2018) 14.

${ }^{45}$ The orange in the Irish tricolour was intended as a gesture of inclusion towards the protestant community, but this gesture has not ingratiated the flag to that community in Northern Ireland.

${ }^{46}$ See for one of many examples, Hugh O'Connell, 'FF TD: United Ireland could celebrate The Twelfth and rejoin Commonwealth' Irish Independent, December 18 ${ }^{\text {th }}, 2019$.

${ }^{47}$ See Article 29.4.2; Kelly (n 28) [5.3.34]-[5.3.37].
} 
monarch, notwithstanding Ireland's status as a republic. Indeed, the majority of Commonwealth countries at present are republics.

Beyond this, the British monarch could be acknowledged in the Irish Constitution in some more specific form. Any such option would require constitutional changes. The British monarch could, for example, be recognised as a joint head of state alongside the Irish President. Such a constitutional amendment would likely precipitate repeal of the Republic of Ireland Act 1948 -- a state could scarcely describe itself as a republic if its head of state is a monarch. More modestly, the British monarch could be recognised as an important figurehead for a substantial portion of the population, affording constitutional recognition without any formal legal or constitutional status.

\section{$\underline{5.3 \text { Languages and terminology }}$}

The Irish language has been a flashpoint between the communities in Northern Ireland in recent years. ${ }^{48}$ The Irish Constitution provides that Irish is the national and 'first official' language of the State, with English given the status of second official language. ${ }^{49}$ Moreover, most of the institutions of the State are given their Irish titles even in the English text of the Constitution..$^{50}$ There might need to be some changes in this respect, using English names for these offices, making the two languages joint and equal first languages, and/or some guarantee for non-Irish speakers not having to use the language in any official context.

\section{$\underline{5.4 \text { Citizenship }}$}

Allowing those from the Ulster Scots and Ulster British traditions to maintain their identity through retaining British citizenship is a crucial guarantee of the Agreement. The two states confirmed that those born in Northern Ireland had the 'right to hold both

\footnotetext{
${ }^{48}$ See generally, see Daithí Mac Sithigh, 'Official status of languages in the UK and Ireland' (2018) 47(1) Common Law World Review 77.

${ }^{49}$ Article 8. The Irish text is the authoritative version of the Constitution in case of conflict; see Kelly ( $n$ 28) [1.1.16]; Mark de Blacam, 'Official Language and Constitutional Interpretation' (2014) 52(2) Ir Jur 90.

${ }^{50}$ See Doyle (n 44) 15. The Oireachtas, Dáil, Seanad, and Taoiseach are called by their Irish titles within the English text of the Constitution, though their English translations are provided. Article 4 says the State's name is 'Éire, or, in the English language, Ireland'.
} 
British and Irish citizenship' and that this would 'not be affected by any future change in the status of Northern Ireland. ${ }^{51}$ No Irish constitutional settlement could guarantee British citizenship to people in Northern Ireland; this would have to be done by the British state. However, if this were done, the Irish Constitution would have to ensure there were no barriers to its residents maintaining such citizenship. Moreover, full rights of political participation, ${ }^{52}$ and other rights, should be given to those who wished to accept only British citizenship, and not legally become citizens of a united Ireland. This would respect the duty in the Agreement to allow people in Northern Ireland to identify as British or Irish or both. Recent litigation has highlighted that this is a problem that the British government did not fully address after the Agreement. ${ }^{53}$ After Brexit, the problem is even more stark as Irish citizens will enjoy EU citizenship and British citizens will not. ${ }^{54}$ There are no obvious or easy solutions to these quandaries.

\section{Protection of political accommodations}

The purpose of this chapter has been to explore how a united Ireland might be constitutionally designed in a way that strengthens centripetal forces in respect of those from the Ulster Scots and Ulster British traditions. We have considered constitutional amendments that would clarify the constitutional status of devolved institutions in Northern Ireland, organised on a consociational basis. Such measures would minimise the amount of change experienced at the moment of unification and might provide reassurance that those from the Ulster Scots and Ulster British traditions would have the power to protect their interests in the new State, thereby at least reducing antipathy to that State. We have also explored constitutional provisions that would require change to recognise multiple identities or construct a more expansive notion of Irish identity. Underlying this analysis-and indeed all discussion of unification-is a move to legal constitutionalism, in contradistinction to the political constitutionalism that currently predominates in the UK. This distinction can sometimes be overstated; all legal systems

\footnotetext{
${ }^{51}$ Belfast- Good Friday Agreement, Constitutional Issues, para 1(vi)

${ }^{52}$ At present British citizens may vote in Dáil elections but not, unless they are also Irish citizens, at presidential elections or referendums. Only Irish citizens may be elected as President, TDs, or senators.

${ }^{53}$ See Secretary of State for the Home Department v Parker De Souza [2019] UKUT 355.

${ }^{54}$ See de Mars et al. (n 24) 60-65.
} 
in truth show a mix of legal and political constitutionalism. ${ }^{55}$ Nevertheless, unification in any form would involve a constitutional culture shock for Northern Ireland. The terms of unification will be expressed legally rather than primarily through political practice, and given their final authoritative interpretation by judges rather than by politicians.

If the measures considered in this chapter are intended to continue to reassure those from the Ulster Scots and Ulster British traditions, we must also consider safeguards about how these measures will be interpreted and amended. As noted above, the Irish Constitution is ultimately interpreted by the Irish Supreme Court. Some concerns could ariseparticularly but not only for those from an Ulster Scots or Ulster British background-that the unification terms might be interpreted by judges trained in only one particular legal system. The composition of the courts raises issues that go beyond this chapter, including the protection of fundamental rights and the more quotidian challenges associated with merging two legal systems. The membership of the Supreme Court would, at the very least, have to expand to include members of the Northern Ireland judiciary to provide expertise on the law of Northern Ireland. This would not be guaranteed within the framework of the existing Irish Constitution, which currently gives sole discretion on the selection of judges to the government. It might, perhaps, be dealt with informally as a convention with respect to appointments, but we have noted the relative weakness of constitutional conventions in the Irish system. ${ }^{56}$ Should a more far-reaching change be adopted? For example, should the constitutional unification terms, implicitly endorsed in two separate referendums in previously separated jurisdictions, be interpreted by a special court composed of equal numbers from each jurisdiction, with an independent chair? These questions all warrant more detailed consideration on another occasion.

The possibility of later constitutional amendment, as opposed to interpretation, raises different concerns. Any reassurance provided by the political accommodations explored in the previous sections could be undermined if they could be undone using the current constitutional amendment procedure -- a majority vote in both houses of the Dublin parliament, followed by a simple majority in a referendum. As we noted in the Introduction, there are two broad models of unification referendums: settling the terms

\footnotetext{
${ }^{55}$ Aileen Kavanagh, 'Recasting the Political Constitution: From Rivals to Relationships' (2019) 39 King's Law Journal 46.

${ }^{56}$ Such a system operates in Canada with respect to representation on the Supreme Court. In the early years of the Irish state, a convention operated in respect of the appointment of Protestant judges to the Supreme Court.
} 
of unification before or after the referendums. If the constitutional configuration of a united Ireland were unknown before the unification referendums, then the problem of subsequent amendment is not so acute: voters in Northern Ireland would have given their consent to unification without knowing the terms and therefore could expect no special role in protecting those terms. In contrast, however, if the constitutional terms of unification were settled before the unification referendums, then voters in the North might approve unification on a certain basis and find themselves in a unified state wherein those terms could be reversed by simple majorities in parliament and at referendum. Such a risk might not materialise, but the very possibility could be destabilising.

The Irish Constitution, unlike many others, imposes no substantive restrictions on the power of constitutional amendment. We see three broad possibilities for protecting the constitutional terms of unification by limiting amendability. ${ }^{57}$ The most extreme approach would be eternal entrenchment of the terms of the unification settlement, but eternal and absolute entrenchment is problematic: successive generations should seldom be absolutely bound by the choices of the current generation, and certainly not in relation to detailed arrangements for government as distinct from universal values. ${ }^{58} \mathrm{~A}$ second approach would be to make the unification provisions subject to a heightened or doublemajority requirement. While it is difficult to identify what level of heightened majority requirement should apply, a dual-majority requirement that mirrored the unification referendums themselves might be attractive. Such an approach would cohere with the constitutional entrenchment of devolution for Northern Ireland, but might seem out of place if devolution did not continue. Over time, however, it might be perceived as incongruous for 15 percent of the population to retain a veto on certain constitutional changes.

A third approach would be to deploy what Albert terms a safe harbour clause. ${ }^{59}$ This would protect the unification terms from amendment for a period of time, thereafter opening them up to constitutional amendment in the usual way. This would amount to a quasi-transition period: the unification terms would be guaranteed for, say, 10 years but would not necessarily be replaced after that. In particular, if devolution and

\footnotetext{
${ }^{57}$ This speaks only to amendment. Constitutional replacement could legally circumvent any limitations on amendment. However, the conditions for amendment are likely to influence the perceived political legitimacy of any proposal for constitutional replacement.

${ }^{58}$ See German Constitution, Article 1 (on human dignity).

${ }^{59}$ Richard Albert, 'The Structure of Constitutional Amendment Rules' (2014) 49 Wake Forest LRev 913, 952-54.
} 
consociationalism were to continue in a united Ireland, this would provide a means of testing different solutions to the West Belfast question before any decision could be made to discontinue devolution. This would provide an element of certainty for a period after unification, but it would not bind the state indefinitely to structures that proved difficult to operate in practice. Finally, one could combine the last two approaches, so that the unification terms are protected for, say, 10 years, unless a double-majority, North and South, votes in a referendum to amend them.

Might the prospect of amendment after the 'safe harbour' period be problematic for those from the Ulster Scots and Ulster British traditions? Potentially, but it is important not to overstate how easy it is to amend the Irish Constitution currently. The people have repeatedly rejected amendments that would have removed constraints on the government or dominant political parties; and no amendment has ever been approved that was opposed by the main opposition party. ${ }^{60}$ Those from the Ulster Scots and Ulster British traditions may, therefore, have relatively little to fear from the capacity of nationalist parties to build a consensus in favour of amending the constitution to alter the unification terms.

We have seen that the Irish government is, under the existing arrangements, a political co-guarantor of the Agreement. What, if any, role should the British government play visà-vis those from the Ulster Scots and Ulster British traditions in a united Ireland? In particular, should it play an equivalent role regarding those communities to that currently played by the Irish government in informally reflecting the views of, and seeking to protect, the ethno-religious minority in the North? It is not uncommon in comparative constitutional practice to have arrangements where a state with close ties of kinship with a minority in another state has a role as an external guarantor for that minority. ${ }^{61} \mathrm{We}$ consider that such a role might well be appropriate, not least as a potentially important confidence-building measure for those from the Ulster Scots and Ulster British traditions, although we do not underestimate the political tensions to which such an arrangement might give rise. Provided such a role were exercised through the existing Agreement

\footnotetext{
${ }^{60}$ See Doyle (n 44), chapter 10.

${ }^{61}$ Discussed in Venice Commission, Report on the Preferential Treatment of National Minorities by Their KinState, adopted Oct. 19-20, 2001, available at: https://www.venice.coe.int/webforms/documents/?pdf=CDL$\underline{\text { INF(2001)019-e }}$
} 
institutions, authorised by the Constitution, ${ }^{62}$ no constitutional amendment would be required.

\section{Conclusion}

In this chapter, we have identified ways in which centripetal forces could be encouraged in a united Ireland, with a particular focus on the likely concerns of those from Ulster Scots and Ulster British traditions. As we have seen, the continuation of devolution and consociationalism could have a centripetal effect in respect of sympathy while-for the very same reason-unleashing centrifugal forces if a divergence of interests between the North and the rest of the State becomes embedded. In addition, the practical problems it poses for national government might cost so much in terms of state capacity that it offsets the gain of greater sympathy for the state from those of Ulster Scots and Ulster British traditions. When we turned to the identitarian aspects of unification, we saw how core indicia of current Irish constitutional identity could tend to alienate those from Ulster Scots and Ulster British traditions. It is imperative to reconsider these constitutional provisions, not least because of the enduring obligations in the Agreement. But this must be done in a sensitive way if it is not to alienate existing citizens from any unified Ireland. Balancing these centripetal and centrifugal forces is a complex and multi-faceted task, but not an impossible one. The main risk, we suggest, is that insufficient time is given to consider these questions. One consequence of the radically different assessments of the likelihood of a united Ireland is that some of its advocates press on enthusiastically, talking largely to themselves, while those opposed or indifferent to unification opt out of discussion. This latter course is, in our view, unwise. Recent years have shown how quickly politics can change in both the UK and Ireland. Time is required to tease out the constitutional compromises that could underpin the success of a united Ireland, should the people of Ireland North and South ultimately so choose. The analysis in this chapter will, we hope, inform that debate.

\footnotetext{
${ }^{62}$ Article 29.7.
} 